\title{
Evaluation of sustainability in Eastern Amazon under proambiente program
}

\author{
J. S. R. Oliveira $\cdot$ O. R. Kato $\cdot$ T. F. Oliveira $\cdot$ \\ J. C. B. Queiroz
}

Received: 26 July 2007 / Accepted: 8 January 2010/Published online: 22 January 2010

(C) Springer Science+Business Media B.V. 2010

\begin{abstract}
This study evaluates the sustainability of the innovative practices of smallholders who have extended their traditional farming and backyard gardening to other production parcels, such as agroforest systems in Eastern Amazon, Northeast Pará, under the PROAMBIENTE Program at Capim River Pole. According to these smallholders, these practices have assured food supplies and yields with the inclusion into the consumer market through produce diversity obtained by agroforest arrangement and increased purchase of material goods to the system. The smallholders' perceptions also permit the evaluation of the sustainability of their experiences through the "Amoeba" method, which consolidates economic, social, cultural, and environmental indicators.
\end{abstract}

J. S. R. Oliveira $(\bowtie) \cdot$ O. R. Kato

Empresa Brasileira de Pesquisa Agropecuária

(EMBRAPA) Amazônia Oriental, Tv. Enéas Pinheiro,

Belém 66095-100, Brazil

e-mail: romanoirituia@yahoo.com.br

O. R. Kato

e-mail: okato@cpatu.embrapa.br

T. F. Oliveira · J. C. B. Queiroz

Universidade Federal do Pará (UFPA) Instituto de

Ciências Exatas e Naturais. Faculdade de Estatística. Rua,

Augusto Correa, 01, Belém 66075-110, Brazil

e-mail: tfo@ufpa.br

J. C. B. Queiroz

e-mail: joaquim@ufpa.br
Keywords "Amoeba" method .

Innovative practices - Sustainable agriculture

Sustainability indicators

\section{Introduction}

The present study was carried out in Irituia, São Domingos do Capim, Concórdia do Pará, and Mãe do Rio, small cities situated in the Bragatina region, Pará State, Eastern Amazonia which is encompassed by the Socio-environmental Development Program of Family Production (Programa de Desenvolvimento Socioambiental da Produção Familiar-PROAMBIENTE). In this region, with more than 100 years of colonization, the primary forest was transformed into fallow vegetation, primarily caused by slash-and-burn family agriculture activities (Denich et al. 2004).

According to the National Family Agriculture Strengthening Program (Programa Nacional de Fortalecimento da Agricultura Familiar-PRONAF ${ }^{1}$ ), family agriculture is a farming system in which the interaction between management and work prevails. The smallholders themselves direct the production process, emphasizing diversification and the use of family work, which is eventually complemented by hired labour.

The lack of policies geared towards identifying the local realities of the family-farming sector in the

${ }^{1}$ PRONAF is a federal Brazilian program that has the goal of strengthening family agriculture. 
Amazon has been one of the contributing factors to the prevalence of subsistence farming. This type of farming is disadvantageous, not only from an economic viewpoint but also from a social and environmental viewpoint, as it affects the quality of life of smallholders (Costa 1997; Denich et al. 2004).

Within this context, the importance of this study is based on the fact that some smallholders in the region have had the initiative to innovate without scientific support. They have done creating new production arrangements that have allowed their inclusion in the consumer market rather than just their survival or subsistence.

As a result, these smallholders have changed the landscape of their Family Production Units (FPU) by increasing their small farms and backyards to Agroforest Systems (AFSs). These modifications have been termed innovative agricultural experiences in this study, for the systems planned for guaranteeing family agriculture have taken other paths. They include several traditional and new production techniques, such as insertion in the local and regional consumer market and the production of environmental services. These services promote water source protection, thermal comfort at the AFS and conservation of agro-ecosystems fauna and flora.

To evaluate the sustainability of these practices, this study is based on specialized literature (Altieri 2000; Gliessman 2001; Sachs 2001; Costabeber and Caporal 2002) and on the smallholders' perception allowing for the definition and identification of indicators for this study, as a new approach.

In this study, sustainability was evaluated using the "Amoeba" method (Nicholls et al. 2003), which is a simple method that allowed the visualization and the comparison of the indicators.

The statistical hypothesis test confirmed that the production of the diverse AFSs has afforded and assured a large food supply, yields with insertion of products in the consumer market, increased purchase of material goods to the system as well as the promoting of environmental services.

\section{Materials and methods}

\section{Description of study region}

The study was carried out in Northeast Pará, where the PROAMBIENTE Program Rio Capim Pole is located. It encompasses the municipalities of Irituia, São Domingos do Capim, Mãe do Rio, and Concórdia do Pará. The predominant climate at the Pole is hot and humid, which is characteristic of the Amazon region. The total rainfall is over $2,500 \mathrm{~mm} /$ year, and it is distributed in two distinct periods: the rainy period, which lasts from January to July and has a high rainfall index of approximately $80.00 \%$; and the dry period, which lasts from August to December and has less frequent rainfall at $20.00 \%$. The thermal variation is very small, with minimum temperatures between 22 and $23^{\circ} \mathrm{C}$ and maximum temperatures ranging from 30 to $34^{\circ} \mathrm{C}$.

The predominant type of soil is yellow latosol with a medium texture and laterite bands. The terrains are high, tertiary to barrier formations and are constituted by arenite, clay, and siltite. The predominant pedogenic units, in general, present characteristically low natural fertility.

The topography is either flat or slightly undulated, with the exception of the Itabocal zone in the municipality of São Domingos do Capim, where the Taperuçu community lies, with altitudes of up to $80 \mathrm{~m}$.

The family income in Capim River Pole comes from semi-permanent and permanent subsistence crops and animal raising. The commercialization system is based on local business intermediation and on sole intermediaries, who seek to buy produce at its lowest cost.

The subsistence crops include manioc (Manihot esculenta), rice (Oriza sativa), corn (Zea may), and beans (Vigna unguiculata). Semi-permanent and permanent crops consist of black pepper (Piper nigrum), coconut (Cocos nucifera L), orange (Citrus sinensis), banana (Musa X paradisiaca L), açaí (Euterpe oleracea Mart), cupuaçu (Theobroma grandiflorum), graviola (Anona muricato L), taperebá (Spondias mombin L), guava (Psidium guajava L), pineapple (Ananás sativa, Lindl), cashew (Anacardium ocidentale), and pupunha (Bactris gasipaes).

Raising mixed, extensive dairy and beef cattle herds with few heads is the primary form of livestock among the Pole smallholders, who have benefited from credit available in the last 15 years. Cattle herds are more prominent in the municipalities of Irituia and Mãe do Rio than elsewhere in the region. The commercialization of products such as milk stands at $10 \%$, while beef sales account for about $90 \%$. 
Methodology

Stages

To evaluate the sustainability of these innovative practices, this study was carried out in three different stages.

In the first stage, FPU visit forms were drafted to collect information on the following: species diversification, implementation time, intervention, evaluation of the farmed area, production seasonability, education, gender issues, credit access, market insertion, and the use of wood and fire.

In the second stage, an informer network was organized. This network identified seventy-eight FPUs, and it later observed the experiences and the innovative agricultural practices at the sites. Concomitantly, the units were georeferenced with a Global Positioning System (GPS), Garmin Plus II, and recorded by image digitalization.

In the third stage, of the seventy-eight FPUs with agroforest diversification, eighteen were selected. The main criterion was to have from fifteen to fifty species of plants in their AFS parcels. The evaluation form was also drafted and applied at this stage with scores from zero to ten.

\section{Indicators}

The indicators dimension used to evaluate the sustainability were economic, social, cultural, and ecological.

The economic dimension was characterized by favourable economic results at the expense of depredating the base of natural resources, which are essential to future generations. In the specific case of the economic indicator, a comparison between the Traditional System and the Innovative System (AFS) was established.

The social dimension was considered plausible when human beings attained a better quality of life by the production and consumption of quality foods.

The cultural dimension was identified by means of the know-how, knowledge, and values of local populations and their use as the starting point in the processes of rural development.

The ecological and environmental dimension was identified by non-environmentally aggressive social practices that strengthen the existing social relations. Table 1 shows the criteria for these dimensions.

\section{Methodology of evaluation of sustainability \\ by the "Amoeba" method}

The "Amoeba" method was used to evaluate sustainability based on scores (the scores are the same as the criteria listed in Table 1) assigned by the people interviewed. This method uses a radar graphic with a polygon shape, and its area is the variable response.

MATLAB was used to calculate the area $\left(\mathrm{mm}^{2}\right)$ and perimeter $(\mathrm{mm})$ of the "Amoebas" of each smallholder relative to each indicator. From smallholders' suggestion, the economic indicator, which had two Amoebas, was used for comparison of the traditional and the innovative systems.

A comparison of the area medians was performed with the hypothesis test with $t$-Student (Eq. 1) for the difference of the population medians based on two or more paired samples.

$$
\begin{gathered}
\left\{\begin{array}{l}
H_{0}: \mu_{1}-\mu_{2}=0 \\
H_{1}: \mu_{1}-\mu_{2} \neq 0
\end{array}\right. \\
t_{n-1}=\frac{\bar{d}-0}{s_{d} / \sqrt{n}}
\end{gathered}
$$

where $\bar{d}$ is the sample difference median, $s_{d}$ is the sample difference standard deviation, and $n$ is the difference sample size.

Variable standardization was used to obtain a scale to make up the four indicators from the individual areas (Eq. 2). This eliminated scale and measurement unit effects through the median and standard deviation of the indicator summation adding five, according to the method described by Daniel (2000).

$I_{\text {ip }}=5+\frac{\bar{I}_{i}-\overline{\bar{I}}}{S_{I}}$

where $I_{\text {ip }}=$ value of standardized indicator, $\bar{I}_{i}=$ median of indicator $i$ "Amoeba" area, $\overline{\bar{I}}=$ median of the "Amoeba" medians of all indicators, $S_{i}=$ standard deviation of the "Amoeba" medians of all indicators, and $5=$ constant added by Calorio (1997).

Standardization by means of Eq. 3 was used to compose the scale from 1 to 10 as established in this study: 
Table 1 Dimension and criteria of indicators used to evaluate sustainability

\begin{tabular}{|c|c|}
\hline Dimension & Criteria \\
\hline Economic & $\begin{array}{l}\text { 1st—drudgery at the implementation of the systems } \\
\text { 2nd-drudgery for the maintenance of the systems } \\
\text { 3rd-drudgery considering cropping and product transformation } \\
\text { 4th-system cost } \\
5 \text { th-yields } \\
\text { 6th-crop association and raising system } \\
\text { 7th-food supply } \\
\text { 8th-product commercialization of each system } \\
\text { 9th-credit access for each system } \\
\text { 10th-purchase of material goods to the system }\end{array}$ \\
\hline Social & $\begin{array}{l}\text { 1st—family access to formal education } \\
\text { 2nd-access to health care } \\
\text { 3rd-access to leisure } \\
\text { 4th-participation in the local social organization } \\
5 \text { th-access to technical support and rural extension (Assistência Técnica e Extensão Rural—ATER) } \\
\text { 6th-gender issues } \\
\text { 7th-access to information-media } \\
\text { 8th-access to public offices (legal and governmental) } \\
\text { 9th-participation in political decisions involving the community and place of living } \\
\text { 10th-overcoming discrimination against rural origin }\end{array}$ \\
\hline Cultural & $\begin{array}{l}\text { 1st-conservation of genetic material for plantation } \\
\text { 2nd-autonomy to plant, preserving customs or simply ignoring them } \\
\text { 3rd-cultural assimilation } \\
\text { 4th-youth interest in innovative systems } \\
\text { 5th-maintenance of religious festivity traditions, parties, and relations with the imaginary-legends } \\
\text { and myths } \\
\text { 6th-participation in religion } \\
\text { 7th-use of slash-burning, whether still constant or not } \\
\text { 8th-use of medicine resources offered by fallow vegetation } \\
9 \text { th-if eating habits have been influenced or not or if they are mixed } \\
\text { 10th-know-how about the biophysical environment and the production systems }\end{array}$ \\
\hline $\begin{array}{l}\text { Ecological and } \\
\text { environmental }\end{array}$ & $\begin{array}{l}\text { 1st—current soil condition } \\
\text { 2nd-water source protection } \\
\text { 3rd-thermal comfort at the AFS } \\
\text { 4th-production and use of firewood } \\
5 \text { th-presence of fauna } \\
\text { 6th-extractivism in secondary forest areas } \\
\text { 7th-extractivism in bordering wooded areas } \\
\text { 8th-appearance of pests and diseases in AFS areas } \\
9 \text { th-pest and disease control } \\
\text { 10th-conservation of agro-ecosystems fauna and flora }\end{array}$ \\
\hline
\end{tabular}


$I_{\text {ip } 10}=2 \times\left[I_{\text {ip }}-\frac{\operatorname{Max}\left(I_{\text {ip }}\right)}{\operatorname{Min}\left(I_{\text {ip }}\right)}\right]$

where $I_{\mathrm{ip} 10}=$ value of standardized indicator $\mathrm{i}$ in the scale from 1 to $10, I_{\text {ip }}=$ value of standardized indicator $\mathrm{i}, \operatorname{Max}\left(I_{\mathrm{ip}}\right)=$ the largest standardized indicator, and $\operatorname{Min}\left(I_{\mathrm{ip}}\right)=$ the smallest standardized indicator.

Equation 3 shows that the value of standardized indicator depends on the maximum and minimum, i.e. the variability of indicators. Therefore, this composition is only possible if indicator variances are identical.

\section{Results}

Comparison of the traditional and the innovative systems

Table 2 and Fig. 1 show the area and perimeter statistics for the traditional and the innovative systems for the economic indicator of the eighteen smallholders. It may be observed that the medians of the areas and of the perimeters of the innovative system are on average larger than those of the traditional system by 63.05 and $33.87 \%$, respectively.

To test the difference of the area medians of the two systems, the value of $t_{\text {calculated }}$ obtained was 5.410 and, therefore, larger than $t_{\text {table }}=3.251$, with $P=0.000$. The hypothesis that the areas of the system "Amoebas" are equal was rejected. As expected, the difference of the median perimeter of the two systems was also significant, with values of $t_{\text {calculated }}=6.320$ and $P=0.000$. Thus, according to the "Amoeba" methodology, the innovative system has the largest area and perimeter, indicating that it is more sustainable than the traditional system.

The statistical analysis is in agreement with the statement that the innovative system presently used

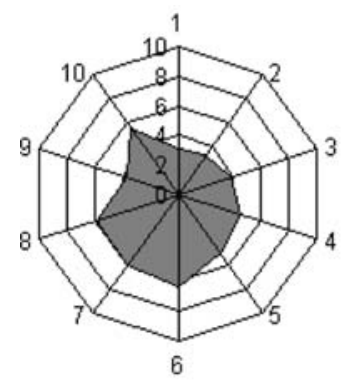

(a)

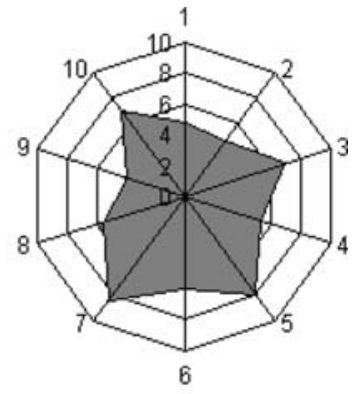

(b)
Fig. 1 "Amoeba" of: a the economic traditional system $\mathbf{b}$ and the innovative system

by the smallholders is economically more indicated for obtaining foods and products, as increment of "Amoeba" area associated with highest scores attributed by smallholders in Table 1 (economic dimension), the major polygon's vertices were 7th-food supply; 5th-yields and 10th-purchase of material goods to the system.

Analysis of the four indicators

Table 3 shows the statistics of the "Amoeba" area medians $\left(\mathrm{mm}^{2}\right)$ of the four indicators used considered for the eighteen smallholders of the innovative system.

The paired $t$-test (Section "Methodology of evaluation of sustainability by the "Amoeba" method", Eq. 1) was used to verify if the medians of the "Amoeba" areas of the four indicators were equal. Table 4 shows that the only significant correlation is that of the cultural and ecological environmental indicators.

Figure 2 shows social indicator "Amoeba". The highest scores were 10th-overcoming discrimination against rural origin; 9th-participation in political decisions involving the community and place of living, and 4th-participation in the local social organization.

Table 2 Area and perimeter for the traditional and the innovative system "Amoebas" for the economic indicator of the eighteen smallholders

\begin{tabular}{|c|c|c|c|c|}
\hline \multirow[t]{2}{*}{ System } & \multicolumn{2}{|c|}{ Area $\left(\mathrm{mm}^{2}\right)$} & \multicolumn{2}{|c|}{ Perimeter (mm) } \\
\hline & Median & Standard deviation & Median & Standard deviation \\
\hline Traditional & $52,753.60$ & $22,242.36$ & $1,004.37$ & 194.69 \\
\hline Innovative & $86,013.22$ & $23,644.78$ & $1,344.57$ & 142.41 \\
\hline
\end{tabular}


Table 3 Statistics for the median area of the "Amoebas" of the indicators considered for the eighteen smallholders

\begin{tabular}{lrlllr}
\hline Indicator & \multicolumn{2}{c}{ Area $\left(\mathrm{mm}^{2}\right)$} & & \multicolumn{2}{c}{ Confidence interval 95\% } \\
\cline { 2 - 3 } & \multicolumn{1}{ll}{ Median } & Standard error & & Lower limit & Upper limit \\
\hline Economic & $86,013.21$ & $5,573.13$ & & $74,254.94$ & $97,771.41$ \\
Social & $108,472.90$ & $9,501.96$ & & $88,425.54$ & $128,520.30$ \\
Cultural & $153,281.50$ & $6,709.36$ & & $139,126.00$ & $167,437.00$ \\
Ecological environmental & $137,376.50$ & $8,121.10$ & & $120,242.40$ & $154,510.50$ \\
\hline
\end{tabular}

Figure 3 shows cultural and ecological environmental indicators "Amoeba". The correlation between indicators was significant ( $p$-value $=0.017$ ).

For the cultural indicator, the highest scores were 3rd-cultural assimilation; 10th-know-how about the biophysical environment and the production systems, and 1st-conservation of genetic material for plantation.

On the other hand, to ecological environmental, the highest scores were 2nd-water source protection, 3rd-thermal comfort at the AFS, and 10thconservation of agro-ecosystems fauna and flora.

The cultural and ecological environmental indicators show much larger areas, suggesting that the cultural background had great influence on the formation of the innovative system. The practices of the knowledge accumulated by past smallholder generations have been translated into the environmental services produced in the FPUs, which are concerned with the distribution and the use of resources in the long term, that is, by both present and future generations.

Figure 4 was obtained according to methodology described in Section "Methodology of evaluation of sustainability by the "Amoeba" method" using Eqs. 2 and 3. As the test of the hypothesis of variance equality using the Levene test gave a probability of $P=0.406$. This means that the variances may be
Fig. 2 "Amoeba" of the social indicator

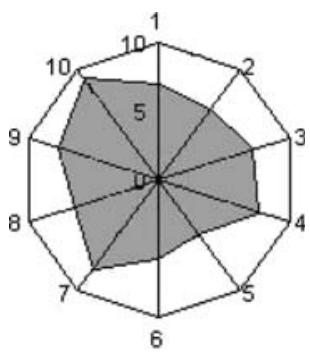

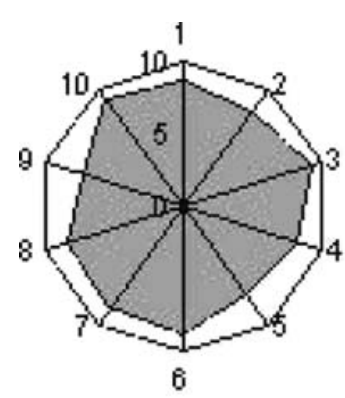

(a)

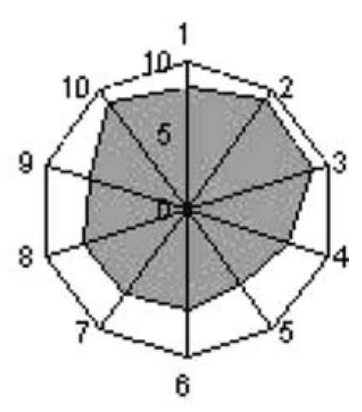

(b)
Fig. 3 "Amoeba" of the a cultural and ecological environmental indicators

considered equal and that standardization does not affect the indicators. This figure shows that cultural and environmental indicators are the largest contributions to the area of the "Amoeba".
Table 4 Correlation between "Amoeba" areas and paired $t$-Student test for the "Amoeba" indicator medians

Boldface values correspond to significant correlation at the level $\mathrm{a} / 2=2.5 \%$ (Bilateral test)

\begin{tabular}{|c|c|c|c|c|}
\hline \multicolumn{3}{|l|}{ Correlation } & \multicolumn{2}{|c|}{ Paired $t$ test } \\
\hline Indicator pairs & Value & $P$ & $t$ & $P$ \\
\hline Social \& cultural & 0.179 & 0.477 & -4.226 & 0.001 \\
\hline Social \& economic & 0.354 & 0.149 & 2.453 & 0.025 \\
\hline Social \& ecological environmental & 0.158 & 0.530 & -2.510 & 0.022 \\
\hline Cultural \& economic & 0.314 & 0.205 & 9.272 & 0.000 \\
\hline Cultural \& ecological environmental & 0.552 & 0.017 & 2.232 & 0.039 \\
\hline Economic \& ecological environmental & 0.332 & 0.178 & -6.277 & 0.000 \\
\hline
\end{tabular}




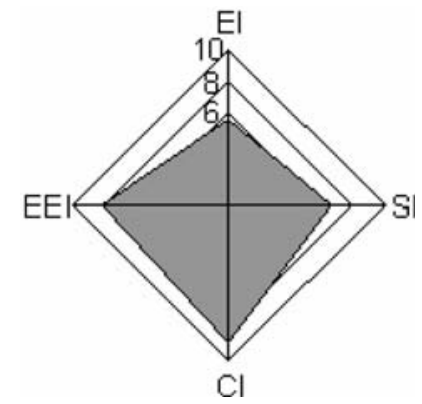

Fig. 4 Indicator composition: EI-economic indicator; ISsocial indicator; $\mathrm{CI}$-cultural indicator and EEI-ecological environmental indicator

\section{Conclusions}

The participation of smallholders in the evaluation of sustainability is a new approach of the problem. The use of a simple technique ("Amoeba") with statistical methods permitted to the indicator consolidation and, therefore, to confirm the hypothesis in this study.

The crises of the traditional system have driven some smallholders to use the territory differently and with competence in the form of innovative experiences, thereby turning crises into creativity. The AFSs are prominent among these innovations.

The production of diverse AFSs has permitted and assured a large food supply, yields with insertion into the consumer market, and increased purchase of material goods to the system.

The cultural and ecological environmental indicators showed good results, with emphasis on environmental services suggesting that the cultural background had great influence on the formation of the innovative system.

It is recommended to increase the size of the samples in other areas, due to spatial scale, since the universe of family agriculture in the Amazon is very large and poorly investigated.

\section{References}

Altieri M (2000) Agroecologia: a dinâmica produtiva da agricultura sustentável, 2nd edn. Federal University of Rio Grande do Sul, UFRS, Brazil

Calorio CM (1997) Análise da Sustentabilidade em estabelecimentos agrícolas familiares no Vale do GuaporéMato Grosso, Cuiabá. Dissertation, Federal University of Mato Grosso, Brazil

Costa FA (1997) A diversidade estrutural e desenvolvimento sustentável: novas de política de planejamento agrícola para Amazônia In: Ximenes $\mathrm{T}$ (ed). Perspectivas do desenvolvimento sustentável (uma contribuição para Amazônia 21), Belém: Federal University of Para, UFPA/ NAEA, Brazil

Costabeber JA, Caporal FR (2002) Possibilidades e alternativas do desenvolvimento rural sustentável. $1^{\circ}$. Congresso Internacional sobre Agricultura Familiar e Desenvolvimento Sustentável. Federal University of $\mathrm{St}^{\mathrm{a}}$ Maria, RS, Brazil

Daniel O (2000) Definição de Indicadores de Sustentabilidade para Sistemas Agroflorestais. Doctoral thesis. Federal University of de Viçosa, MG, Brazil

Denich M, Vielhauer K, Kato MS, Block A, Kato OR, Abreu Sá TD, Lücke W, Vlek PLG (2004) Mechanized land preparation in forest-based fallow systems: the experience from Eastern Amazonia. In: Nair PKR, Rao MR, Buck LE (eds) New vistas in agroforestry: a compendium for the 1st world congress of agroforestry. The Netherlands, Kluwer, Dordrecht, pp 91-106

Gliessman SR (2001) Agroecologia: processos ecológicos em agricultura sustentável, 2nd edn. Federal University of Rio Grande do Sul, UFRS, Brazil

Nicholls C, Altieri M, Dezanet A, Feistaeur D, Lana M, Baptista M, Ouriques M (2003) Método agroecológico rápido e de fácil acesso na estimativa da qualidade do solo e saúde do cultivo em vinhedos. Personnal Comunication, Califórnia, USA

Sachs I (2001) Caminhos para o Desenvolvimento Sustentável/ Organização. Paula Y. Stroh-Garamound, Rio de Janeiro, Brazil 